\title{
Triangular concept of legal pluralism in the establishment of consumer protection law
}

\author{
Muldri Pudamo James Pasaribu* and Ningrum Natasya Sirait \\ Doctoral Program in Law, Universitas Sumatera Utara, Indonesia
}

\begin{abstract}
The new paradigm in legal pluralism is closely related to the phenomenon of globalization. Laws of various levels move into limitless territories. There is a strong contact and adoption between international, transnational, national and local laws. Such circumstances make it impossible for mapping that a certain law (international, national, local) is separated from other law systems. This is a normative legal research with a comparative law approach. Law as a global phenomenon has the common values throughout the world, namely ethical moral values, social values and formal values of the state. The same values apply to the consumer protection law in Indonesia. Law Number 8 of 1999 on Consumer Protection (UUPK) in Indonesia was developed on the basis of legal pluralism. The data were analyzed using a Triangular Concept of Legal Pluralism developed by Werner Menski. In conclusion, UUPK is a form of legal pluralism. It is enacted based on the community needs, legitimized by the state and based on values and ethics.
\end{abstract}

\section{Introduction}

Legal pluralism is not a new phenomenon in Indonesia. Customary law used to be the original Indonesia's legal system. However, in its development, Indonesia adopted the Islamic Law System, and then, due to a long period of Dutch colonialism, it adopted the Dutch legal system rooted from the Roman law system. Therefore, examining the Indonesia's legal system cannot be done by determining to which cluster the legal system is oriented, either to a civil law system or to a common law system. This is the evidence that the pluralism of the legal system has existed in Indonesia since a long time ago.

In addition, it has been proved that in some parts of the archipelago there was once a common law legal system, e.g. in Kalimantan under the British colonies and in Papua under the Dutch colonies. Moreover, geographically, these two areas are very close to the countries adopting Anglo-Saxon legal system, such as Papua with Australia, Kalimantan with Malaysia, Brunei Darussalam and Singapore. After its independence, the Republic of Indonesia enacted a legal unification referring to a Civil Law legal system.[1]

If the historical reality mentioned above is used as a reference or benchmark in categorizing Indonesia legal system orientation, it can be said that it lies on the both sides. This means that Indonesia adopts a mixed legal system or Mixed System. The tendency of

\footnotetext{
*Corresponding author: muldripasaribu73@gmail.com
} 
adopting a mixed system is also inevitable due to the continuous recognition of the original law of Indonesia (Adat Law/Customary Law) as a legal source. In addition, the continuous adoption of a legal codification as a civil law system shows that Indonesia adopts a legal pluralism.[1]

Until recently, there have been many concepts and attributes about legal pluralism proposed by the experts. The legal pluralists of the 1970s proposed the concept of legal pluralism, although somewhat varied, as the existence of more than one legal system within the same social field. In line with this idea, Sally Engle Merry argues, "legal pluralism is generally defined as a situation in which two or more legal systems coexist in the same social field".[2]

The legal pluralism should always consider the state laws on the one hand and the people's laws on the other. Such people's laws include customary law, religion, customs or other social conventions that are viewed as law. In addition, in the current era of globalization, it is necessary to take into account the presence of international law in the arena of legal pluralism. In the empirical reality, especially in the field of economy and human rights, the effect of international laws is very visible.[3]

The consumer law and the consumer protection law are two areas that are difficult to separate and draw the boundaries. Essentially, the consumer protection law is part of the consumer law. The consumer law serves as the overall principles and rules governing relationships and problems of supply and use of products (goods and/or services) between providers and consumers in social life.[4]

The scope of consumer protection law as a special part of the consumer law is the overall principles and rules governing and protecting consumers in the relationships and problems of supply and its users in social life. For consumers, it takes legal principles that prevent dishonest acts in business, or the existence of market dominance with various business practices. It is possible that such business practices hamper the entry of new companies or harm other companies in unnatural ways. As for the end-user, it is necessary to have legal rules that guarantee the safe conditions of every product for human consumption, supplemented with correct, clear, honest and responsible information.[4]

Based on the above explanation, it can be defined that consumer law and consumer protection law in Indonesia are established based on three elements that include the normative element as the basis of its applicability, the sociological element as the element of society needs and the value element needed as the ethics in its enactment.

Werner Menski offers a conceptual approach called "Triangular Concept of Legal Pluralism". According to Menski, law as a global phenomenon has the common values throughout the world, namely ethical moral values, social values and formal values of the state. Essentially, a law comprises a number of cultural variations and always requires plurality. Facing the globalization era, modern legal experts have abandoned three classical legal approaches - normative (positivism), empirical (sociological, anthropological, psychological and others), and values and moral (philosophical) approaches - that tended to be narrow by using only one type of approach. However, the theory of triangular concept of legal pluralism uses all the three approaches.[5]

\section{Formulation of the Problem}

The problem of this research is formulated as: how is the formation of Consumer Protection Law in Indonesia viewed from the triangular concept of legal pluralism, and how is the possibility of that concept uses in a different legal system?

\section{Research Method}


This type of research is an analytical descriptive legal research. The data sources were secondary data comprising primary, secondary and tertiary legal materials.[6] Normative legal methods refer to legal norms in various laws and regulations.[7] Data collection is done through library research study, i.e. document data collection, literature and studying the provisions of related legislation. The qualitative data analysis then will be used through a comparative law approach which is oriented to the legal theory approach as the base of thinking. Comparative approaches are used by comparing legal systems with one another, which has more or less similarities, so that the similarities and differences between the legal systems were found.[8] Triangular concept of legal pluralism theory by Menski then tested to get a new concept related to the problems to be answered in this research.

\section{Literature Review}

In a global context, law has similarities all over the world, in the sense that everywhere the law is made up on the basis of ethical values, social norms, and rules made by the state, although later in reality, there are many more specific cultural variations. The Menski's legal pluralism approach uses the three main types of legal approaches: laws created by the society, laws created by the state and laws that arise through values and ethics.[5]

According to Gerald Turkel, to understand the legal system comprehensively there are three approaches that can be used in, that is: (1) The moral approach to law, which focuses his attention on the moral basis of the law and its legal validity is the legal consistency with ethics external or moral values, (2) The jurisprudence approach to law, which is focused his attention to the independence of the law, and his legal validity is internal law consistency with the rules of the norm, and principles of the law itself; and, (3) The sociological approach to law, which focuses attention on law and social action, where the validity of the law is consequences law for its people.[9]

The theory and approach advanced by Gerald Turkel later developed further by Werner Menski by combining the three approaches so that a new theory is emerging known as the theory of triangular concept of legal pluralism.

Werner Menski offers a new legal interaction that would serve as the solution, through the idea of a new legal pluralism, with a combination of state law (positivism), society (socio-legal approach), and natural law (moral/ethic/religion).[5]

The law as a tree, then we cannot look at parts of the tree partially, but totally. We should not look at any of the woods only in function as "roots" (which in law are the societies and cultural values) that absorb food from the soil, we should not look at any of the woods only in the form of stems that reinforce the tree (the law is the law positive), and we should not look at any of the woods only as branches of the branches that extend into the sky and in various directions to inhale the heavenly scent (in law are moral, religious, and ethical values).[10]

\section{Results and Discussion}

Consumer interests have long been a concern in all countries across the world, and consumer protection issue is one of the most important issues in the world today. The reason is that all members of the society are consumers who need to be protected from the quality of goods or services provided by the producers to the public. In reality, consumer is the decisive party in the fostering of capital to drive the wheels of the economy.[11]

The consumer protection movement in Indonesia is becoming popular from the similar movement in the United States. The Indonesian Consumers Foundation (YLKI), popularly known as a pioneer of consumer advocacy in Indonesia, was established on 11 May 1973. 
YLKI together with BPHN (National Legal Development Board) formulated the Consumer Protection Bill. In the late 1990s, the Consumer Protection Law was not only championed by consumer agencies and the Ministry of Commerce, but it was also strictly required by the international financial institution (IMF/International Monetary Fund).[12] Another important development was that in 1962 President John F. Kennedy sent to the so-called Special Message on Protecting the Consumer Interest to the American Congress, where he established four rights that every consumer possessed: the right to safety, the right to be informed, the right to choose, the right to be heard.[13]

In addition, the factors that influence the formulation of UUPK in Indonesia are the emergence of several cases that harm consumers and end with a solution that does not satisfy the consumers. In the case of the Republic of Indonesia against Tan Chandra Helmi and Gimun Tanno [14] known as the case of toxic biscuits, for example, the consumers' claims were viewed only from the criminal and administrative aspects. As a result, the victims or consumers were not compensated on the basis of civil liability. Another case involved Janizal et al. against PT Kentamik Super Internasional, known as the Perumahan Narogong Indah Case. In this case, the developer was won, and the developer even sued back the consumers who were considered to have committed defamation. [15]

In this case, there is a group in the society whose role is very important to note in causing legal movement. Epistemic community is an entity in which academicians, experts, scientists or legal drafters interact across state boundaries to generate the concept of global norms used as the solution to a certain problem. The definitive conceptual framework of an epistemic community is a network of professionals with recognised expertise and competence in a particular domain and an authoritative claim to policy relevant knowledge within that domain or issue-area.[16]

Furthermore, UUPK was issued by the Government of Indonesia on 20 April 1999. The UUPK came into effect on April 20,2000. This period was the beginning of the recognition of consumer protection and since then it has become legitimately formal as a means of legal force for the consumers and as a demand for the business actors as the providers/producers.

In its current development, there is a tendency to expand the scope of the consumer protection law, as done by The Economic Law and Improved Procurement System Project (ELIPS), which proposes 9 (nine) items of consumer protection law formulation: (1) inequalities in bargaining power; (2) freedom of contract versus justice in contract; (3) requirements to provide information to consumers, including general announcement law and financial announcement law; (4) regulations on the seller's behaviour/conduct, including false guidance/direction and cunning in the trade; (5) regulations on product quality, including product warranty and safety; (6) access to credit (reporting, credit, nondiscrimination); (7) limits of the right to terminate the guarantee period; (8) price regulation; and (9) rectification. [17]

Consumer protection in the era of globalization becomes very important because consumers do not only have universal rights but also very specific rights both related to its situation and condition. Thus, in addition to universal values, the legislation should also contain specific values in accordance with the values that grow in the society. Changes in the social structure always require changes in the law. [18]

Carefully studying the articles in UUPK reveals that some of the provisions contained in the law are in accordance with the values of Islamic business ethics. Although written in different wordings, the substance and purpose of such provisions are just the same - to protect consumers. For example, the provisions contained in Article 7 letter a) a, b, c, d, e regulate the necessity of having good intentions in doing business. In addition, Article 8 paragraph $(2,3,4)$ defines the obligation to sell goods with good quality. The prohibition of concealing defective goods in Article 8, not playing oaths (providing incorrect 
advertisement information) and not rivalling friends by fooling consumers with gifts are substances containing ethical elements.[19]

Related to the Triangular Concept of Legal Pluralism approach, these three facts above, can be described:

Ethics/Moral/Religion:

Contains ethical value in the articles

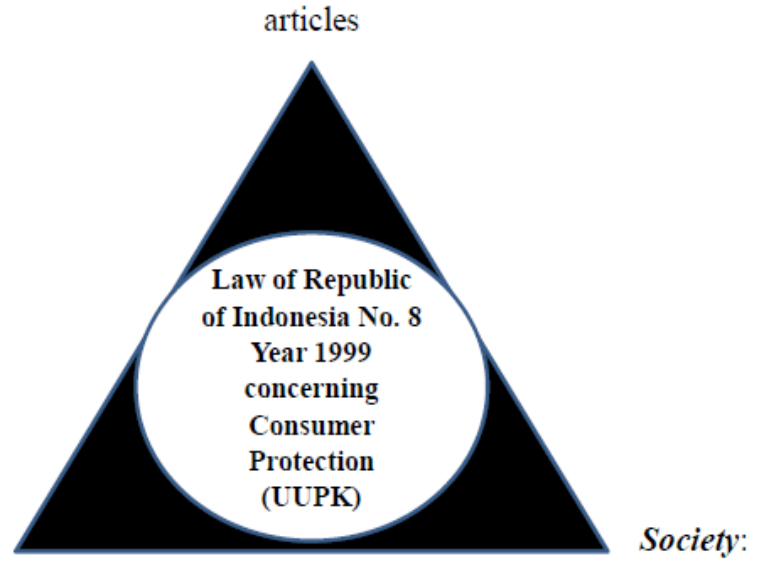

State: Legitimated by Legislative

-Encouragement by Institution or community organization

- Cases

Fig. 1. Establishment of Indonesian Consumer Protection Law with Triangular Concept of Legal Pluralism approach

Figure 1 above shows that the establishment of the UUPK cannot be separated from the development of the three regions around the circle. This UUPK area is a legal pluralism. If viewed from the Triangular Concept of Legal Pluralism, regulations in the field of consumer protection will continue to grow. The area of pluralism in the triangle will continue to expand. One of the examples that will expand such area is a series of endorsements of the establishment of the World Trade Organization (WTO) which has been ratified by Indonesia through Law Number 7 of 1994 on Endorsement of Agreement Establishing the World Trade Organization. This endorsement enables products from other countries to meet the Indonesian market, which has implications for the increasing interest of Indonesian consumers to purchase.

Today, the growth of internet users increasing rapidly. The internet is an effective medium for businesses to introduce and sell goods or services to potential customers from all over the world. The practice of online transactions, namely e-commerce, causes many problems that tend to harm consumers. One of them is a legal problem in conducting transactions. E-commerce transactions are also a sale and purchase contract that is the same as conventional transactions. The difference is the media used. In e-commerce transactions, the media used is electronic media, namely the internet. So that the agreement or contract created is through online. In making an obligation, it must be clear in terms of national legal aspects through consumer protection law, as well as aspects of international law through international agreements or harmonization of laws.

Strengthening consumers through consumer education will also greatly affect the changes in consumer behaviour. This development is what makes the need to do 
amendment of UUPK to protect the development of modern consumers' needs, such as this online shopping behaviour.

The amendment of UUPK can be done by considering the eight principles under Fuller's principles of legality, (1) a system of governance operates through general norms, and all or most of the norms partake of the following properties: (2) they are promulgated to the people who are required to comply with them; (3) they are prospective rather than retrospective; (4) they are understandable rather than hopelessly unintelligible; (5) they do not contradict one another and do not impose duties that conflict; (6) they do not impose requirements that cannot possibly be fulfilled; (7) they persist over substantial periods of time, instead of being changed with disorienting frequency; and (8) they are generally given effect in accordance with their terms, so that there is a congruence between the norms as formulated and the norms as implemented.[20]

One of the conditions is found in the number 7 (seven) that is consistent at all times. According to Fuller, the stipulation that the law must be constant/ consistent at all times is not absolute, since the law must respond to changes occurring at any time (Introducing such frequent changes in the rules). The law should be able to respond to changes that occur at any time, meaning that the regulations in the field of consumer protection should be able to accommodate all kinds of cases or problems such as online shopping behaviour that arises from the development of the times in order to avoid the legal vacuum.

If this concept of legal pluralism from Menski related to the concept of the three elements of the legal system introduced by Lawrence M. Friedman, then we can say that the plurality of laws concerns not only the substance or structure but also the higher plurality of elements of "legal culture" which includes the plurality of existing habits, the plurality of opinions that exist, the plurality of existing beliefs, as well as the plurality of ways of thinking and acting in the field of law.[21]

The differences which exist between civil law and common law should not be exaggerated. It is also important to note that differences on many issues exist both among civil law and among common law countries. The differences between civil law and common law systems are more in styles of argumentation and methodology than in the content of legal norms. By using different means, both civil law and common law are aimed at the same goal and similar results are often obtained by different reasoning. The fact that common law and civil law, despite the use of different means arrive at the same or similar solutions is not surprising, as the subject-matter of the legal regulation and the basic values in both legal systems are more or less the same.[22]

Even though it be admitted that the civil law and the common law started from opposite extremes, it is sometimes said that as a result of the movements each has made in the direction of the other, there is no longer much difference between them. The same social needs, and similar economic and technical conditions, have led to the adoption of similar solutions for their legal problems.[23] The similar between the civil law system and the common law system is that both are open to the development of the times.

\section{Conclusions}

Globalization is not only indicated by borderless state but also by borderless law. The laws of a certain region are able to penetrate into other limitless territories. International and transnational law can penetrate into the territory of any country, even into the local area down to the grassroots level. On the contrary, local laws and principles are also adopted in part or in whole and may become an international law. This is called the legal pluralism.

The establishment of UUPK can be studied through Triangular Concept of Legal Pluralism approach, where the social pressure of local and international community encourages the state to legitimize it. The interaction between moral values, ethical values 
and religious values with the state and the society in the UUPK ultimately creates a new legal pluralism. The national market is also increasingly open through the process of economic globalization. Starting with the 1994 World Trade Organization agreement. In this situation the government must further increase legal efforts to ensure legal certainty and people prosperity. In line with the development of modern consumer society's needs, it is necessary to do amendment of legislation that would fit the development and needs of the society.

A legal system is a part of the life of the people in every country. Different characteristics influenced the culture of the people. Each legal system may have some advantages and deficiencies. If a foreign legal system has some advantages, there is a possibility to incorporate them in the domestic legal system. In that way the resulting convergence of the two legal systems can only contribute to their common goal of creating a fair and just legal system which can provide legal certainty and protection to all citizens and legal persons.

\section{References}

1. N. Qamar, Perbandingan sistem hukum dan peradilan: Civil law system dan common law system, p. 3-4 (Refleksi, Makassar, 2010)

2. S. E. Merry, Legal pluralism, Law Soc. Rev. 22: 869-896 (1988)

3. S. Irianto, Sejarah dan perkembangan pemikiran pluralisme hukum dan konsekuensi metodologisnya, Wacana Antropologi 1 (1998)

a. Z. Nasution, Hukum perlindungan konsumen: Suatu pengantar, p. 21-22 (Diadit Media, Jakarta, 2006)

4. W. Menski, Perbandingan hukum dalam konteks global: Sistem Eropa, Asia dan Afrika, Translated by M. Khozim, p. 228-242 (Nusamedia, Bandung, 2008)

5. Amiruddin and Z. Asikin, Pengantar metode penelitian hukum, p. 118 (Raja Grafindo Persada, Jakarta, 2004)

6. S. Soekanto and S. Mamuji, Penelitian hukum normatif, p. 10 (Raja Grafindo Persada, Jakarta, 2004)

7. Soeroso, Perbandingan hukum perdata, p. 6 (Grafika, Jakarta, 2005)

8. G. Turkel, Law and Society Critical Approachs, p. 10 (Allyn and Bacon, USA, 1996)

a. Ali, Menguak teori hukum dan teori peradilan, p. 159 (Kencana, Jakarta, 2009)

9. J. Sidabalok, Hukum perlindungan konsumen di Indonesia, p. 23-24 (Citra Aditya Bakti, Bandung, 2014)

10. Sudaryatmo, Memahami hak anda sebagai konsumen, 1st Edition, p. 23 (PIRAC, Jakarta, 2001)

11.Z. B. Carroll, Busines and society, in K. Bertens, Pengantar etika bisnis, p. 248 (Kanisius, Yogyakarta, 2013)

12. Putusan PN Tangerang No. 30/Pid.B/1990/PN/Tng

13. Putusan PN Jakarta Pusat No. 3138/K/Pdt/1994/PN.Jkt.Pst. Putusan Kasasi MA No. 3138/K/Pdt/1994.

14. P. M. Hass, Introduction: eepistemic communities and international policy coordination, Int. Organ., special issue: Knowledge, power, and international policy coordination, Cambridge Journals, 46:1; 1-35 (1992)

15.Z. Nasution, Sekilas hukum perlindungan konsumen, Majalah hukum dan pembangunan, Tahun XVI, 6, 70 (1986)

16. Watson, Comparative law and legal change, Lecture at King's College on 6 February 1978, and the author wishes to dedicate it to Otto Kahn-Freund. 
17. N. S. Imaniati, Perlindungan konsumen salah satu upaya penegakan etika bisnis pada masyarakat islam dalam era globalisasi, Jurnal Mimbar, 4 Th.XVII (2001)

18. L. L. Fuller, The morality of law, 2nd ed., chap. 2. (Yale University Press, New Haven, Conn., 1969)

19. D. Johnston, Roman law in context, p. 6 (Cambridge University Press, United Kingdom, 2004)

20. Pejovic, Civil law and common law: two different paths leading to the same goal, Victoria University of Wellington Law Review, 32;817-842 (2001)

21. J. Dainow, The civil law and the common law: some points of comparison, The American Journal of Comparative Law, 15:3; 419-435 (1966) 